\title{
CROSS-BOREHOLE FLOW TESTS AND INSIGHTS INTO HYDRAULIC CONNECTIONS IN FRACTURED MUDSTONE AND SANDSTONE
}

\author{
John H. Williams, U. S. Geological Survey, Troy, NY \\ Pierre J. Lacombe, U. S. Geological Survey, West Trenton, NJ \\ Carole D. Johnson, U. S. Geological Survey, Storrs, CT \\ Frederick L. Paillet, University of Maine, Orono, ME
}

\begin{abstract}
Cross-borehole flow tests provided insights into hydraulic connections in fractured and dipping mudstone and sandstone that were consistent with the lithostratigraphic and structural framework of a VOCcontaminated bedrock research site in west-central New Jersey. Two cross-borehole flow tests were completed. Each test involved measurement and analysis of transient flow in a newly installed deep corehole with a long open interval during short-term pumping and recovery in an adjacent shallow well with a short open interval. The cross-borehole flow test in the mudstone identified a hydraulic connection through a dipping fractured bed between the pumped interval in the well and a flow zone at an intermediate depth in the corehole. The presence of a hydraulic connection between the pumped well and the corehole was not obvious because the water-level response in the corehole was dominated by a shallow zone of high transmissivity, which was hydraulically isolated from the pumped interval. In the sandstone, the cross-borehole flow test identified a hydraulic connection along dipping fractured beds as well as a connection to a deep high-angle fracture that cuts across bedding. These results suggest that application of cross-borehole flow tests at other contaminated fractured-bedrock sites could provide insights into hydraulic connections useful the design and implementation of monitoring and remediation programs.
\end{abstract}

\section{Introduction}

Cross-borehole flow testing is an effective method for providing insights into hydraulic connections in fractured-bedrock aquifers. Two cross-borehole flow tests were recently completed at a VOC-contaminated fractured-bedrock research site. Each test involved measurement and analysis of transient flows in a newly installed, deep corehole during short-term pumping and recovery from a shallow existing extraction or monitoring well with a short open interval. This paper presents the results of the cross-borehole flow tests including identification of hydraulic connections and their relation to the lithostratigraphic and structural framework of the fractured bedrock.

The research site is a decommissioned military facility in Mercer County, west-central New Jersey (fig. 1). The site is underlain by the Lockatong and Stockton Formations of Mesozoic age. The Lockatong Formation consists of laminated to massive mudstone, and the Stockton Formation consists predominantly of sandstone with some shale. Lacombe (2000 and 2002) identified cyclic lithostratigraphic units in the Lockatong and Stockton through the analysis of gamma logs and bedrock cores from the more than 50

Final copy as submitted to SAGEEP for publication as: Williams, J.H., Lacombe, P.J., Johnson, C.D., and Paillet, F.L., 2007, Cross-borehole flow tests and insights into hydraulic connections in fractured mudstone and sandstone, in Symposium on the Application of Geophysics to Engineering and Environmental Problems (SAGEEP), April 1-5, 2007, Denver, Colorado, Proceedings 2007: Denver, Colorado, Environmental and Engineering Geophysical Society, CD-ROM, p. 1140-1152. 
bedrock boreholes at the site. The dip of the bedding is $20^{\circ}$ to $40^{\circ}$ to the northwest. A high-angle fault transects the site and separates the Lockatong from the Stockton. VOC contamination of ground water at the site is predominately in the Lockatong Formation (Lacombe, 2000).
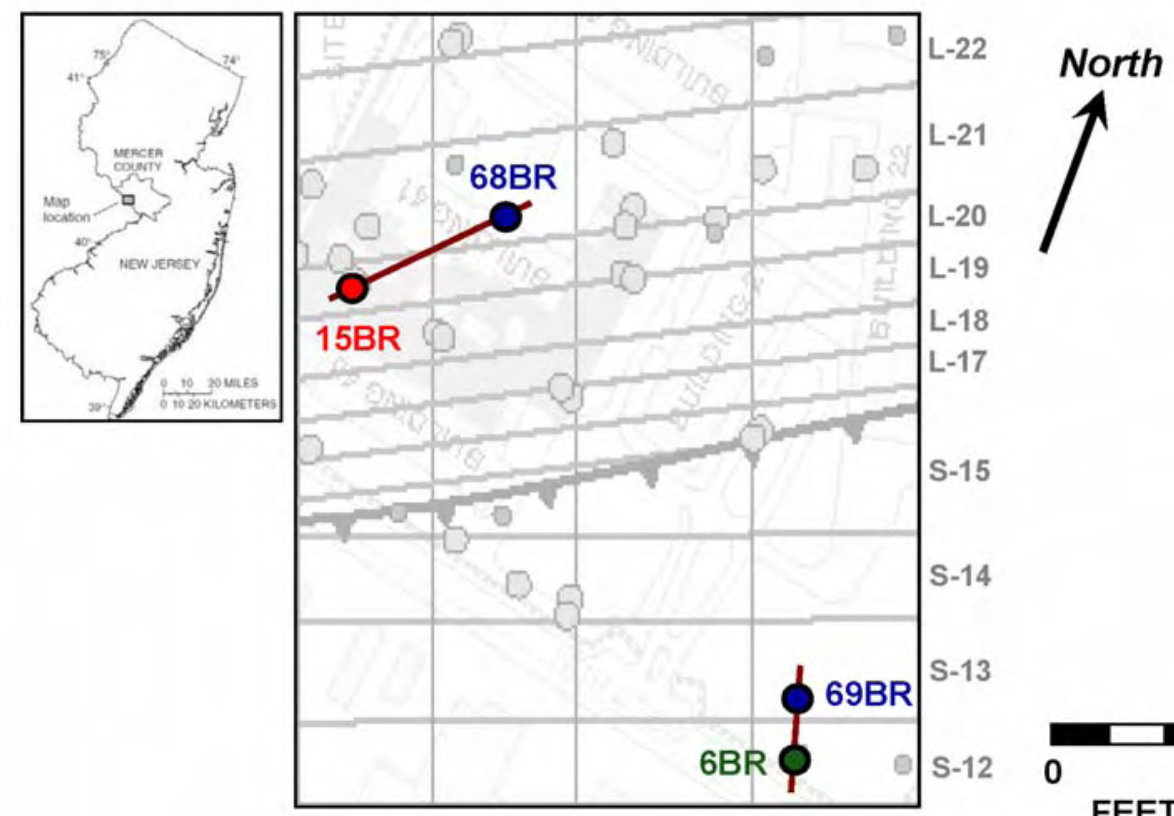

EXPLANATION
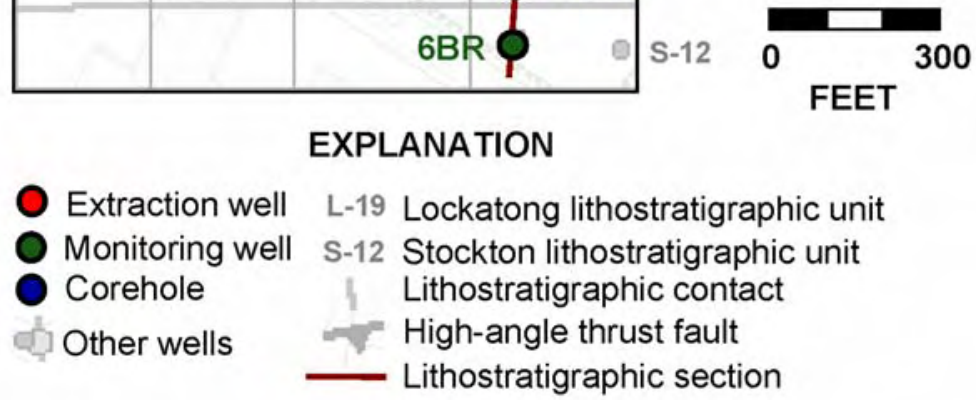

Figure 1. Location of research site and coreholes and wells used in the cross-borehole flow tests and site lithostratigraphic and structural framework (Lacombe, 2000 and 2002).

Borehole-flow tests and analysis methods in fractured bedrock as applied in the present study are described by Paillet (1998 and 2000). Single-borehole flow tests involve collection of a series of flow measurements with a flowmeter stationed above and between fractured flow zones under two sets of quasisteady state conditions, typically the existing ambient condition and a pumped condition. Single-borehole flow tests are analyzed to estimate the transmissivity and hydraulic head of the flow zones intersected by the tested borehole. Cross-borehole flow tests involve collection of a series of flow measurements with a flowmeter stationed above and between fractured flow zones in an observation borehole during pumping and recovery in an adjacent borehole. When a borehole that intersects a fractured flow zone is pumped, drawdown is propagated outward along the hydraulically interconnected fractured network. The generally differing drawdown rates propagating through individual flow zones induce a transient vertical flow in an observation borehole between depths where the flow zones intersect that borehole. The shape of the curve for the transient flow response indicates the hydraulic characteristics of the fractures between the boreholes including their hydraulic connectivity, transmissivity, and storage. The application of the cross-borehole flow test method in fractured and metamorphosed shale is described by Williams and Paillet (2002). 
The cross-borehole flow test analysis was simplified in the present study by pumping from a shallow extraction or monitoring well with a short open interval that intersects a single or closely spaced series of fractured flow zones. As a result, the pumping stress originates only from one short transmissive interval. Pumping from the short open-interval well induces vertical flow in the adjacent deep corehole between the multiple flow zones intersected by the corehole. The flow zones in the long open-interval corehole that are best connected to the pumped well serve as the outflow zones, while the corehole's less well connected or isolated flow zones serve as inflow zones. Transient flows are simulated by numerical modeling methods developed by Paillet (1998 and 2000) and are compared with measured flows to evaluate conceptualizations of the hydraulic connection between the flow zones in the pumped well and flow zones intersected by the observation corehole. Flow zones intersected by the observation corehole are simulated as either hydraulically connected to or isolated from the pumped well.

The cross-borehole flow tests were completed with the cooperation of the U. S. Navy and were supported by the Toxic Substances Hydrology Program of the U. S. Geological Survey. Single- and crossborehole hydraulic tests using inflatable packers, the results of which are presented in this paper for comparison, were conducted and analyzed by Allen M. Shapiro, Claire R. Tiedeman, and Daniel J. Goode of the U. S. Geological Survey as part of the Toxic Substances Hydrology Program.

\section{Corehole 68BR and Well 15BR}

\section{Cross-Borehole Flow Tests}

Corehole 68BR penetrates the Lockatong Formation with a long open interval from 12 to $170 \mathrm{ft}$ below land surface (BLS) (figs. 1 and 2). Analysis of the gamma log and bedrock core indicates that the corehole is open to the Lockatong units 17 to 20 (L-17 to L-20) of Lacombe (2000 and 2002). Optical (OTV) and acoustic televiewer (ATV) and full waveform sonic (FWS) logs and flow, temperature, and fluid resistivity logs under ambient and pumped conditions suggest that corehole 68BR intersects fractured flow zones identified as shallow (40 ft BLS and above), intermediate (94 ft BLS), and deep (144 ft BLS). The identified flow zones correlate with the three depth intervals with the highest transmissivity values as estimated from single-borehole hydraulic tests using an inflatable straddle-packer apparatus described by Shapiro (2001). The shallow flow zone, which has a transmissivity more than an order of magnitude greater than the intermediate and deep flow zones, is within highly fractured and weathered near-surface strata in unit L-20. The intermediate flow zone is at the top of unit L-18 in a black carbon-rich, fissile mudstone bed with strata-bound fractures. The deep flow zone is near the contact between light gray and red mudstone in unit L-17.

Corehole 68BR is $325 \mathrm{ft}$ from well 15BR (figs. 1 and 3). Well 15BR is an open hole from 26 to $41 \mathrm{ft}$ BLS, which is continuously pumped at about $9 \mathrm{gal} / \mathrm{min}$ to extract VOC-contaminated ground water. Analysis of the gamma log from 15BR indicates that this extraction well is open to the lower part of unit L-19. 


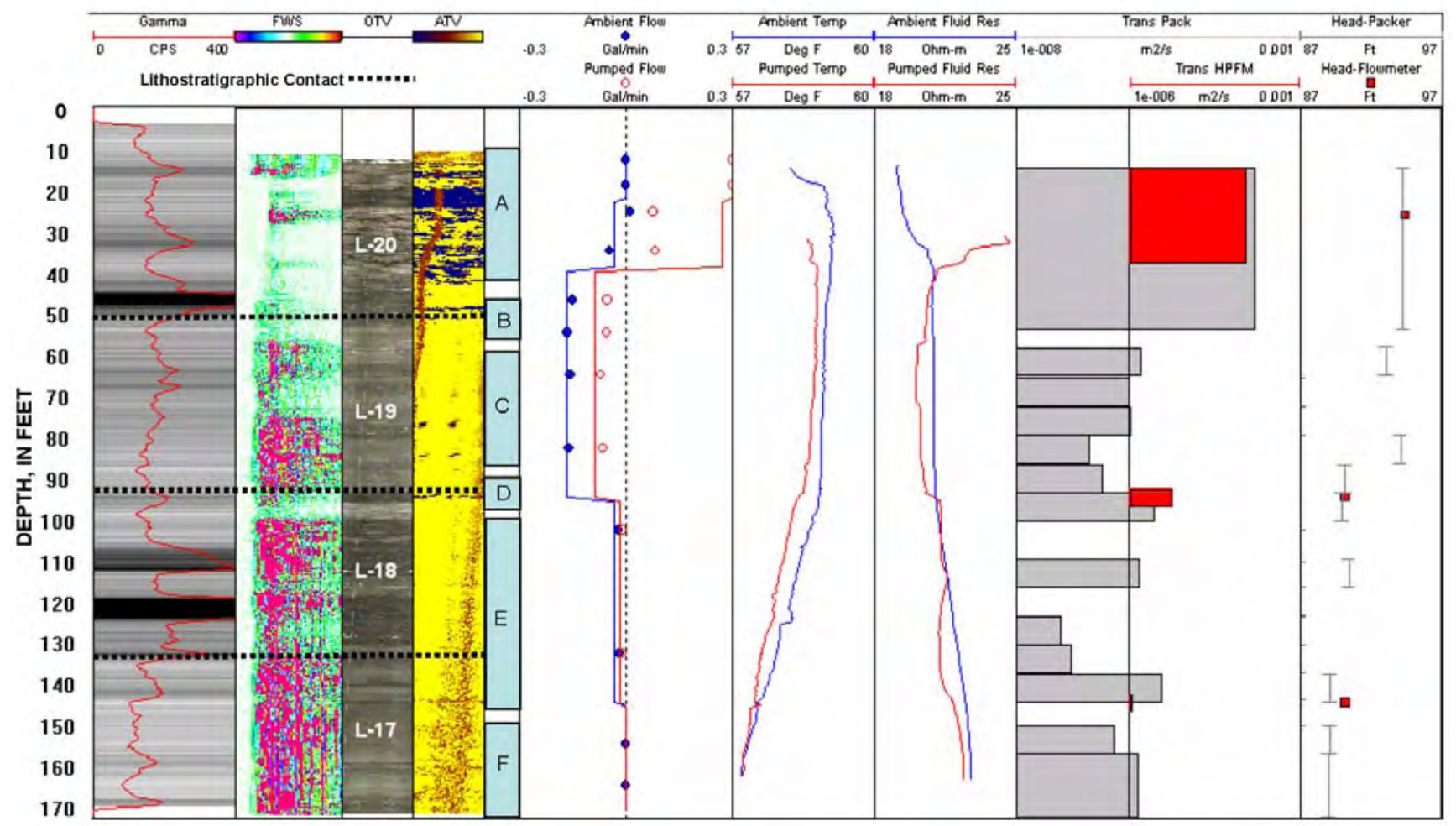

Figure 2. Corehole 68BR logs of gamma; Lockatong lithostratigraphic units; FWS, OTV, and ATV; intervals A through F isolated with inflatable-packer string; flow, temperature, and fluid resistivity under ambient and pumped conditions; flow-zone transmissivity and hydraulic head estimated from flowmeter analysis; and transmissivity and hydraulic head from straddle-packer hydraulic test analysis

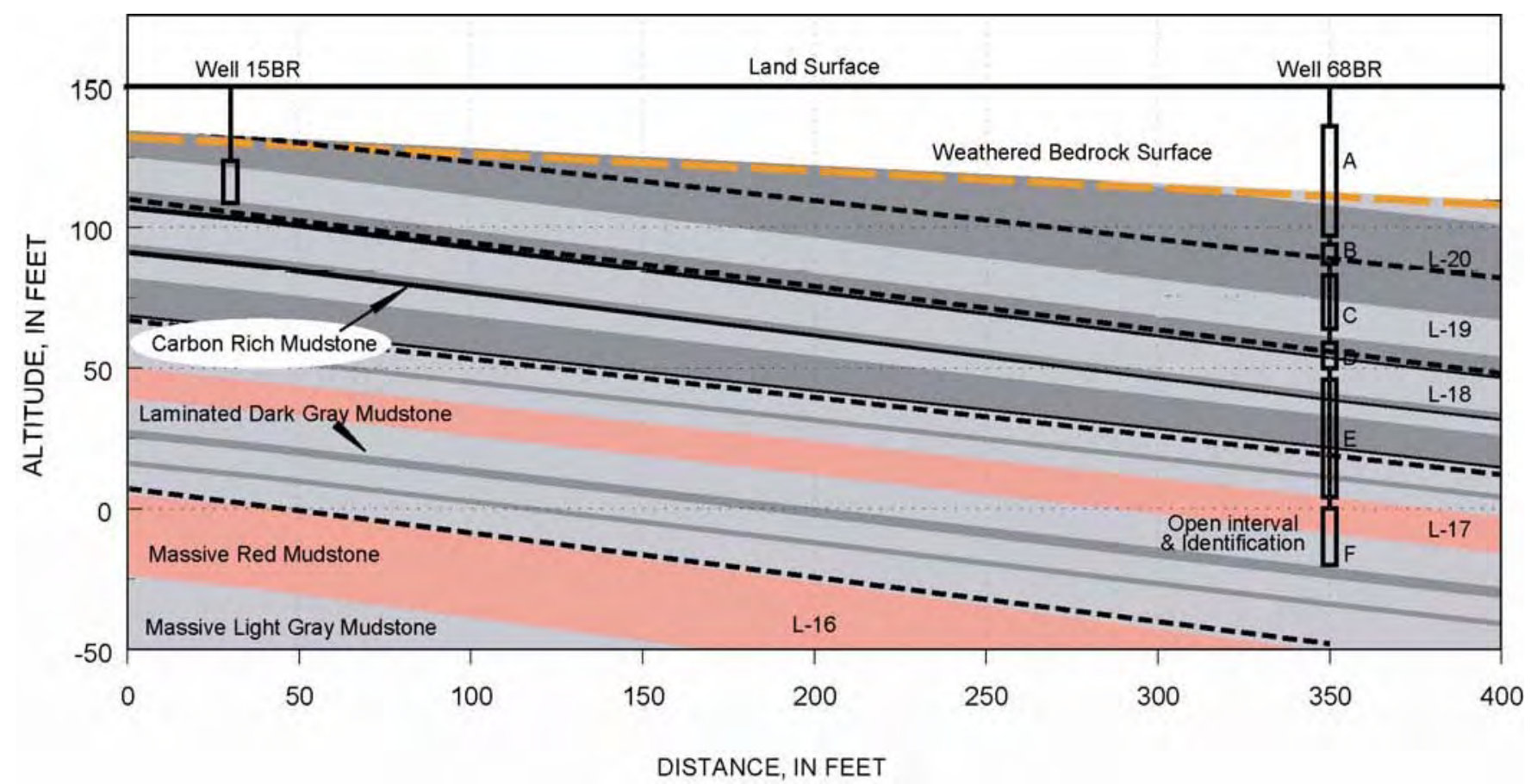

Figure 3. Lithostratigraphic section near corehole 68BR and well 15BR

Vertical flow was measured with a heat-pulse flowmeter at depth stations above and between the shallow, intermediate, and deep flow zones in corehole 68BR under the ambient conditions in which 
extraction well 15BR was continuously pumped (fig. 2). The quasi-steady state flow was downward in the corehole under these existing conditions with the shallow flow zone serving as the zone of inflow, and the intermediate and deep flow zones serving as zones of major and minor outflow, respectively. When corehole 68BR was pumped at $1 \mathrm{gal} / \mathrm{min}$ with a pump temporarily set near the top of the corehole (and with continued pumping in 15BR), the shallow zone contributed all the pumped flow and the downward flow rate from the shallow zone to the intermediate and deep zones was reduced by roughly 50 percent.

The transient flow responses above and between flow zones was measured in 68BR during pumping and recovery cycles in well 15BR. Pumping (at a rate of $9.2 \mathrm{gal} / \mathrm{min}$ ) and recovery in well $15 \mathrm{BR}$ resulted in a water-level change of about $7 \mathrm{ft}$ in well 15BR but less than $0.05 \mathrm{ft}$ in corehole 68BR (fig. 4). Pumping and recovery in well 15BR caused no measurable change in vertical flow above the shallow zone or between the intermediate and deep zones in the corehole. However, pumping in well 15BR caused a small but measurable increase in the downward flow rate between the shallow flow zone and the intermediate flow zone (fig. 5). Modeling the shallow zone in 68BR as hydraulically isolated from and the intermediate zone in 68BR as hydraulically connected to the pumped flow zone in well 15BR provides simulated flows that reasonably match measured flows. Results of the flow test are consistent with the interpretation that the open interval of well 15BR is hydraulically connected to the intermediate flow zone in corehole 68BR through a dipping fractured bed at the top of unit L-18, and hydraulically isolated (or very poorly connected) across bedding from the corehole's shallow and deep zones.

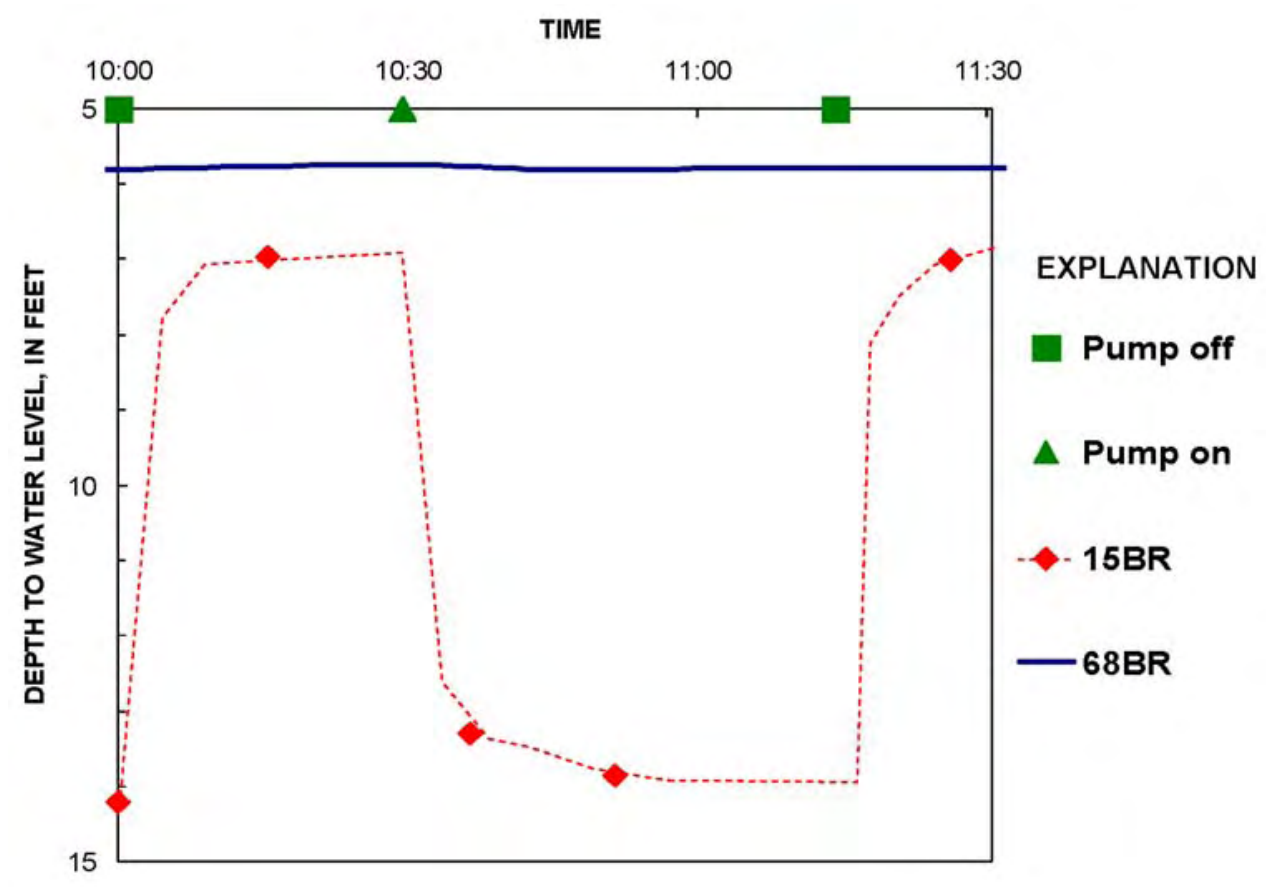

Figure 4. Water levels in corehole 68BR and well 15BR during pumping and recovery in well 15BR. [Dashed line indicates inferred.] 


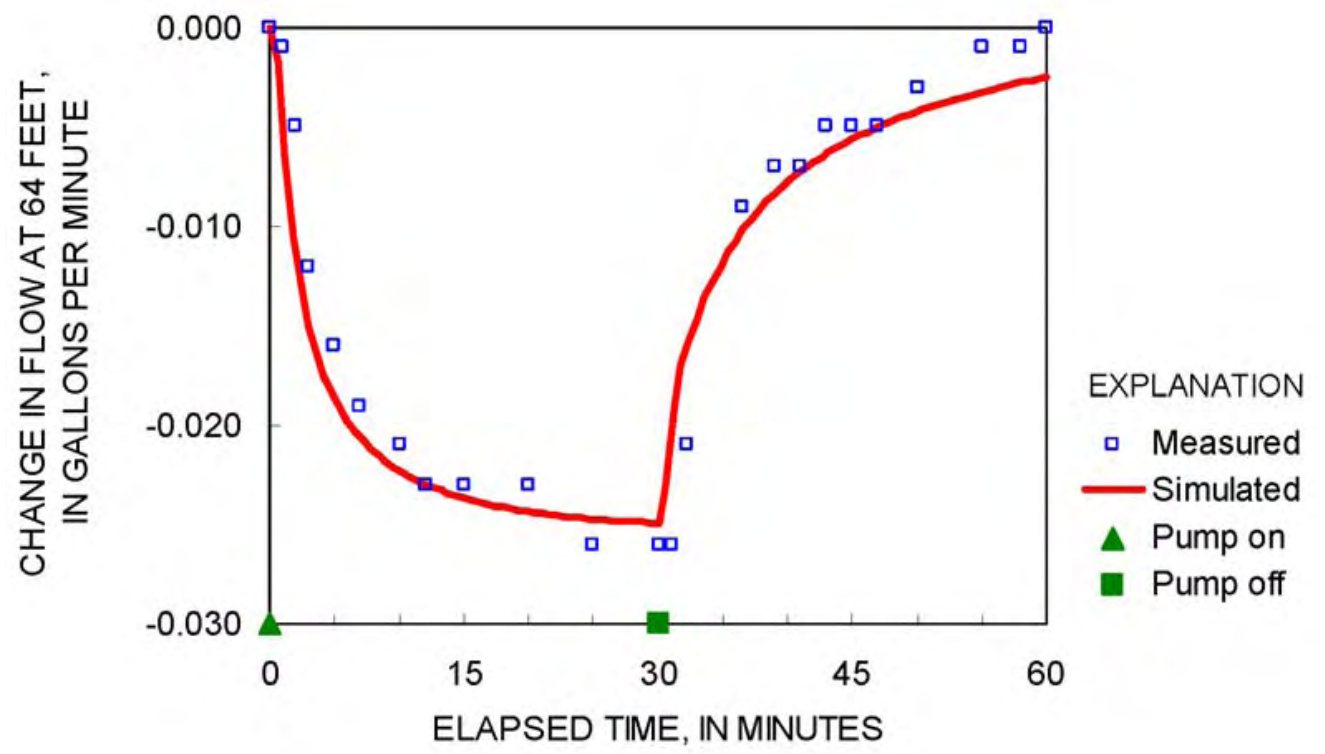

Figure 5. Measured and simulated change in flow between shallow and intermediate flow zones in corehole 68BR during pumping and recovery in well 15BR.

Following geophysical logging and cross-borehole flow and single-hole hydraulic testing, corehole 68BR was completed with a removable string of inflatable packers to isolate depth intervals A through F (figs. 2 and 3). Packer-isolated interval A is from the base of casing to 53.5 BLS and is open to the shallow flow zone. Intervals B and C are from 55.8 to $62.4 \mathrm{ft}$ BLS and 64.7 to $88.6 \mathrm{ft} \mathrm{BLS}$, respectively. Interval D is from 90.8 to $100.1 \mathrm{ft} \mathrm{BLS}$ and is open to the intermediate flow zone. Interval E is from 102.3 to 147.6 ft BLS and is open to the deep flow zone. Interval $\mathrm{F}$ is from $149.9 \mathrm{ft}$ BLS to the bottom of the corehole. Water levels in packer-isolated intervals $\mathrm{A}, \mathrm{C}, \mathrm{D}$, and $\mathrm{F}$ in corehole 68BR were monitored in response to an 8-hour cessation of pumping from well 15BR (fig. 6). Water levels in intervals A and F showed no measurable response to the cessation of pumping. However, the water levels in intervals $C$ and $D$ showed a recovery of about $1 \mathrm{ft}$ during the cessation of pumping with the water level in interval D, which is open to the intermediate flow zone, displaying the most rapid and largest response. The results of the cross-hole recovery test are consistent with the cross-hole flow test analysis further indicating that the intermediate depth intervals in corehole 68BR are hydraulically connected along bedding to the pumped zone in well 15BR, while shallower and deeper intervals are hydraulically isolated across bedding from that zone. The water level measured in corehole 68BR under open-hole conditions (fig. 4) shows no significant change as a result of pumping and recovery in well 15BR because the shallow flow zone, due to its much higher transmissivity, dominates the composite water level and masks the water-level response in the intermediate flow zone. 


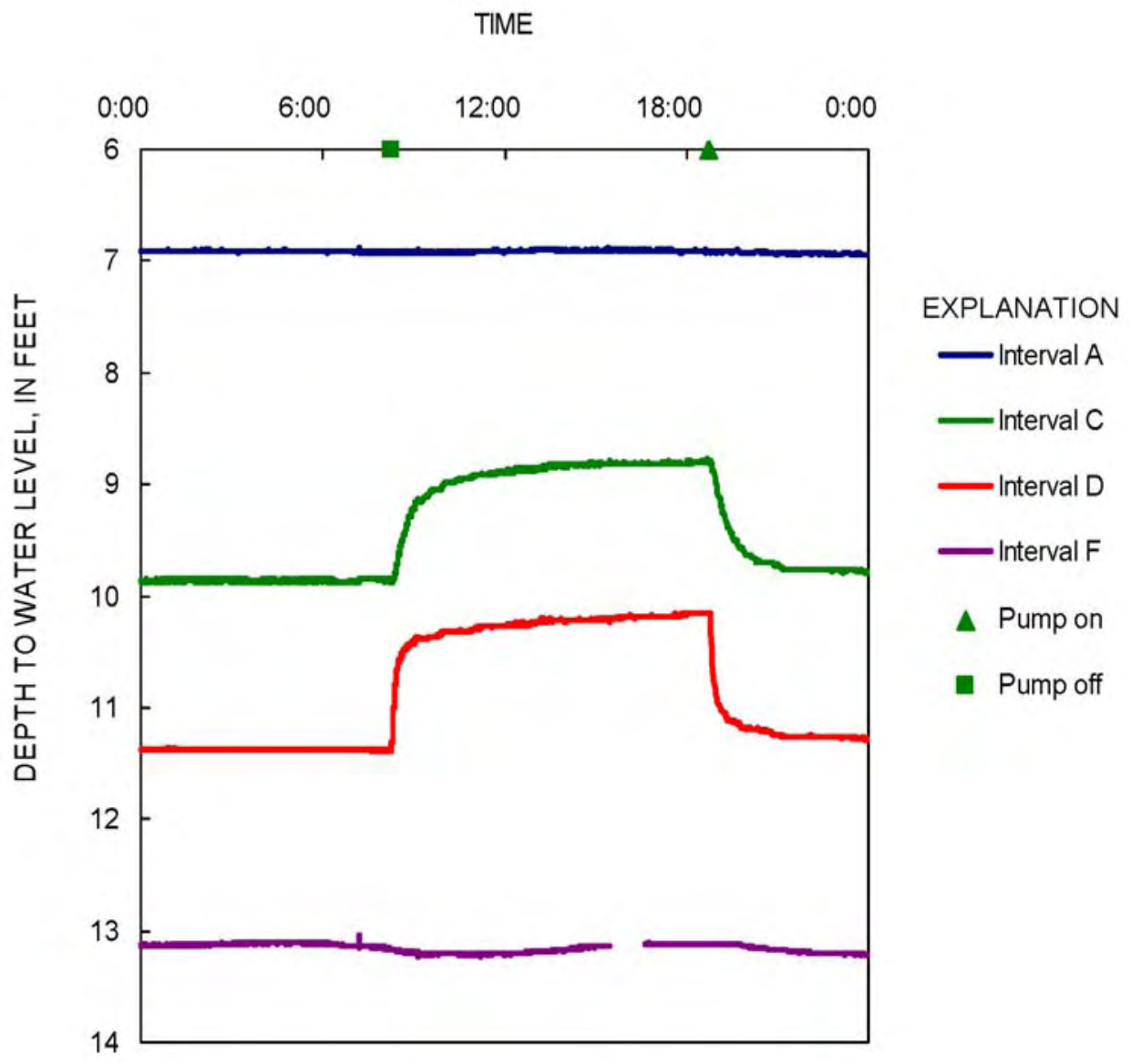

Figure 6. Water-level recovery in packer-isolated intervals A, C, D, and F in corehole 68BR in response to 8-hour long cessation of pumping in well15BR.

\section{Corehole 69BR and Well 6BR}

Corehole 69BR penetrates the Stockton Formation with a long open interval from 30 to $260 \mathrm{ft}$ BLS (figs. 1 and 7). Analysis of the gamma log and bedrock core indicates that the corehole is open to Stockton units 11 and 12 (S-11 and S-12) of Lacombe (2000 and 2002). OTV and ATV logs and flow logs under ambient and pumped conditions suggest that corehole 69BR intersects fractured flow zones identified as shallow (59 ft BLS), intermediate (105, 122, and $132 \mathrm{ft}$ BLS), and deep (232 ft BLS). The transmissivities of the shallow and deep flow zones are roughly equal to the combined transmissivity of the intermediate zones. The shallow flow zone is a fractured bed in the middle part of the S-12 unit sandstone. Strata-bound fractures within this bed have a broad range of dips. The intermediate flow zones are a series of fractured sandstone intervals at the base of unit S-12 and the upper part of unit S-11 with strata-bound fractures that dip to the northwest (parallel to bedding) and to the southeast. The deep flow zone is a high-angle fracture that cuts across a bed of gray sandstone within unit S-11. 


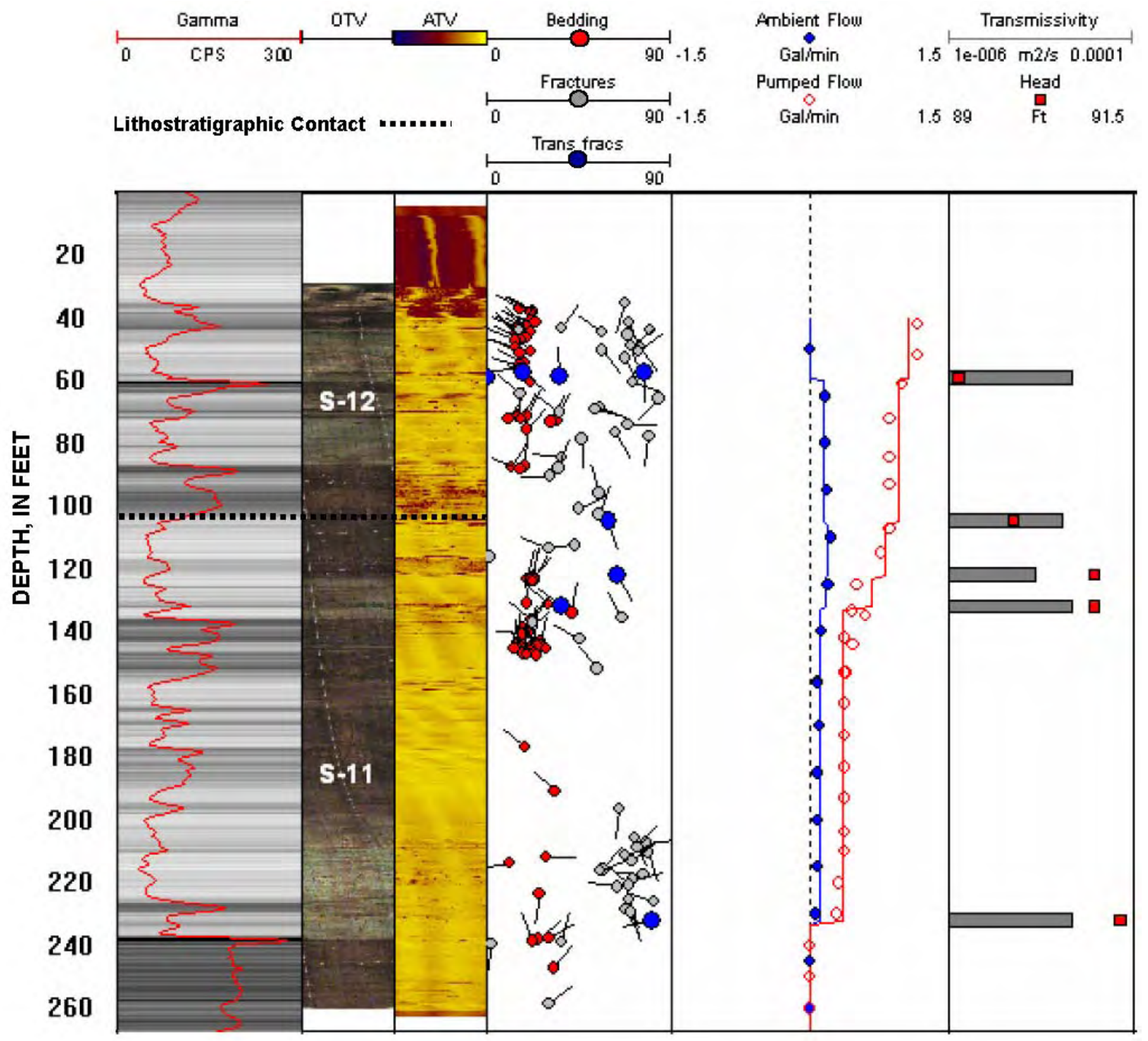

Figure 7. Corehole 69BR logs of gamma; OTV and ATV; Stockton lithostratigraphic units; bedding and fracture dip (dip angle, in degrees, and dip direction indicated by tadpole); flow under ambient and pumped conditions; and flow-zone transmissivity and hydraulic head estimated from flowmeter analysis.

Corehole 69BR is $100 \mathrm{ft}$ downdip of well 6BR (figs. 1 and 8). Well 6BR is a monitoring well open from a depth of 26 to $41 \mathrm{ft} \mathrm{BLS}$. Analysis of the gamma log indicates the well is open to the base of unit S-12 and upper part of unit S-11. 


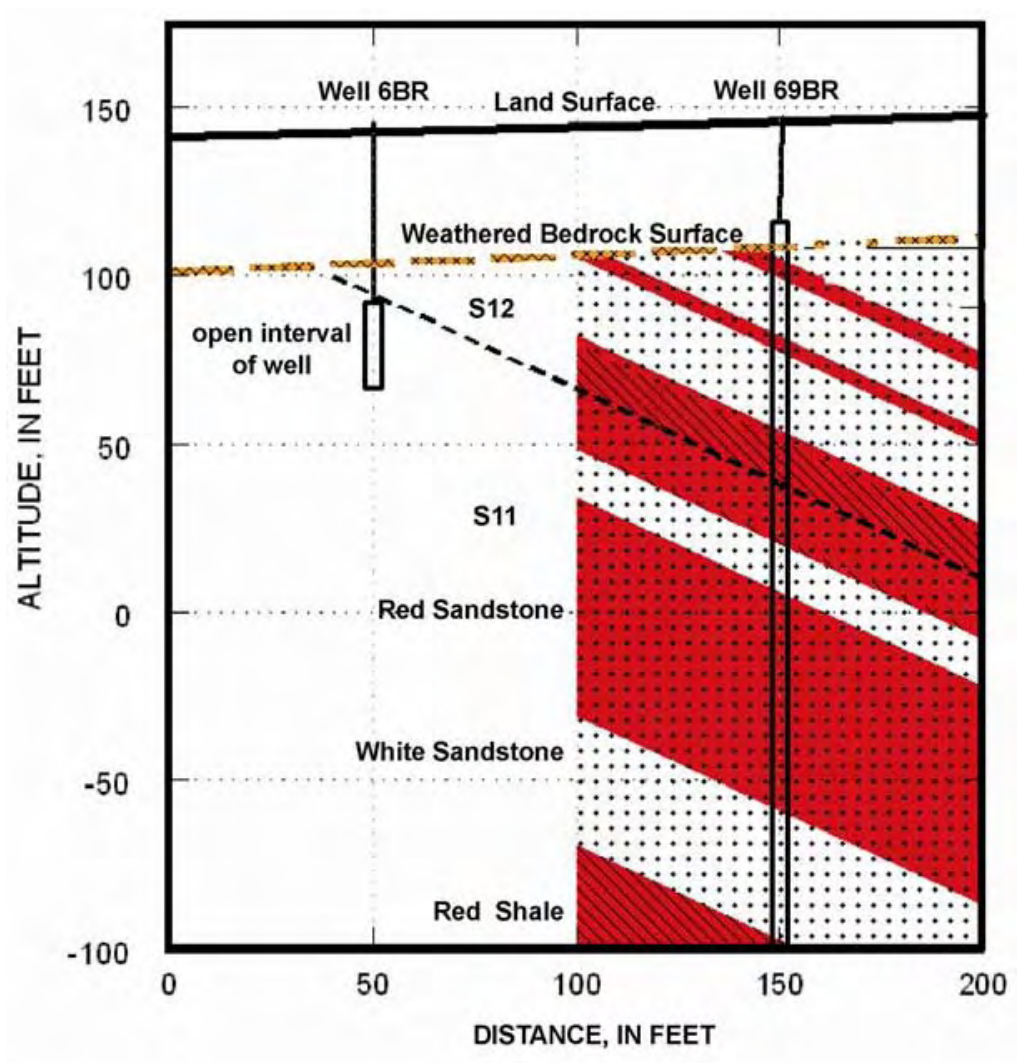

Figure 8. Lithostratigraphic section near corehole 69BR and well 6BR.

Vertical flow was measured with a heat-pulse flowmeter at depth locations above and between the shallow, intermediate, and deep flow zones in corehole 69BR under ambient conditions (fig. 7). Quasi-steady state flow was upward in the corehole with the deep and lower intermediate flow zones serving as zones of inflow, and the upper intermediate and shallow flow zones serving as zones of outflow. When the corehole was pumped at $1 \mathrm{gal} / \mathrm{min}$ with a pump temporarily set near the top of the corehole, the shallow, intermediate, and deep zones each contributed flow to the pump.

The transient flow responses above and between flow zones was measured in 69BR during pumping and recovery cycles in well 6BR. Pumping (at a rate of $5.5 \mathrm{gal} / \mathrm{min}$ ) and recovery in well 6BR results in a water-level change of more than $8 \mathrm{ft}$ in well 6BR and about $1 \mathrm{ft}$ in corehole 69BR (fig. 9). Pumping of well 6BR reversed flow from upward to downward in the upper part of corehole 69BR with the shallow flow zone serving as the zone of inflow and the intermediate flow zones serving as zones of outflow (fig. 10a and 10b). Modeling the 69BR shallow flow zone as hydraulically isolated from, and the intermediate flow zones as hydraulically connected to, the open interval of well 6BR provides simulated flows that reasonably match flows that were measured between the shallow and intermediate zones. Results of the flow test are consistent with the interpretation that the open interval of well 6BR is hydraulically connected to the intermediate flow zones in corehole 69BR through a series of dipping fractured beds at the base of the unit S-12 and in the upper part of the unit S-11, and hydraulically isolated (or very poorly connected) across bedding from the corehole's shallow flow zone. 


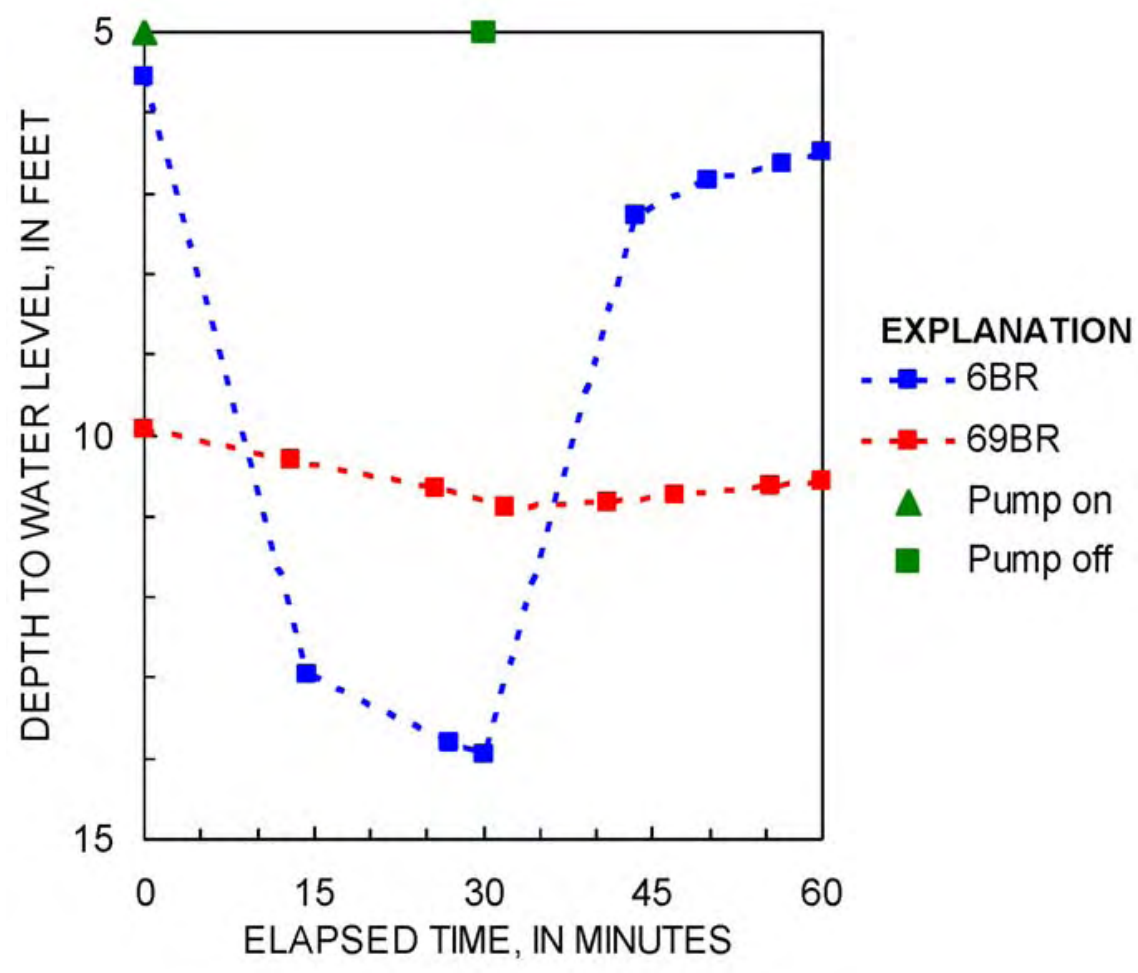

Figure 9. Water levels in corehole 69BR and well 6BR during pumping and recovery in well 6BR. [Dashed lines indicate inferred.]

A.

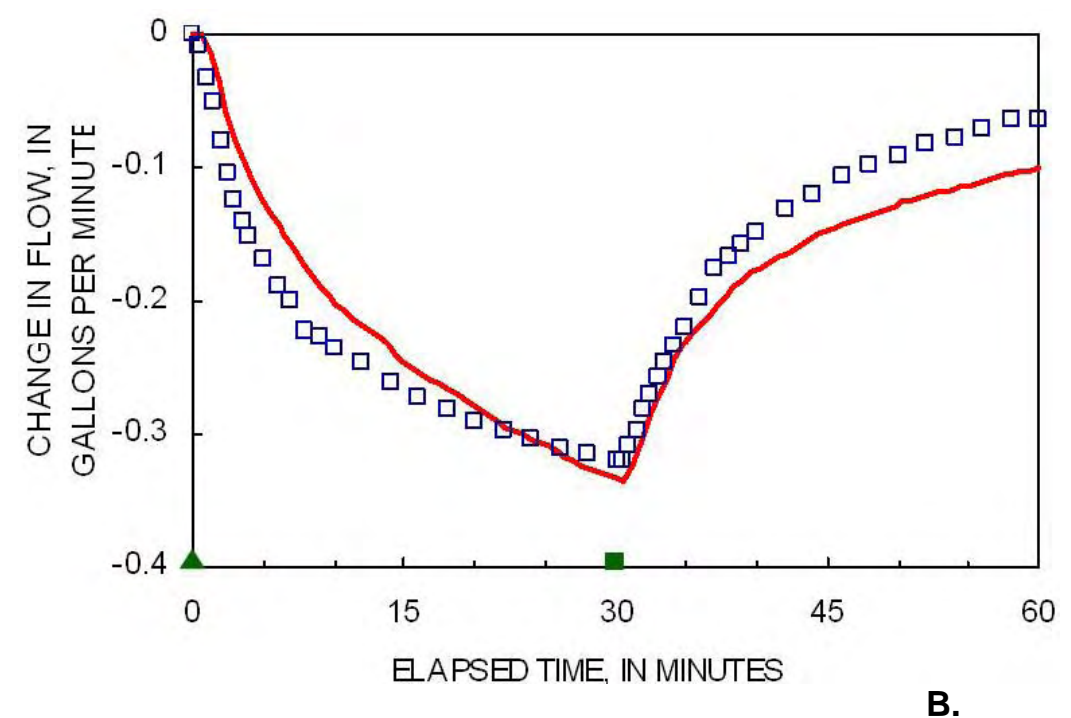




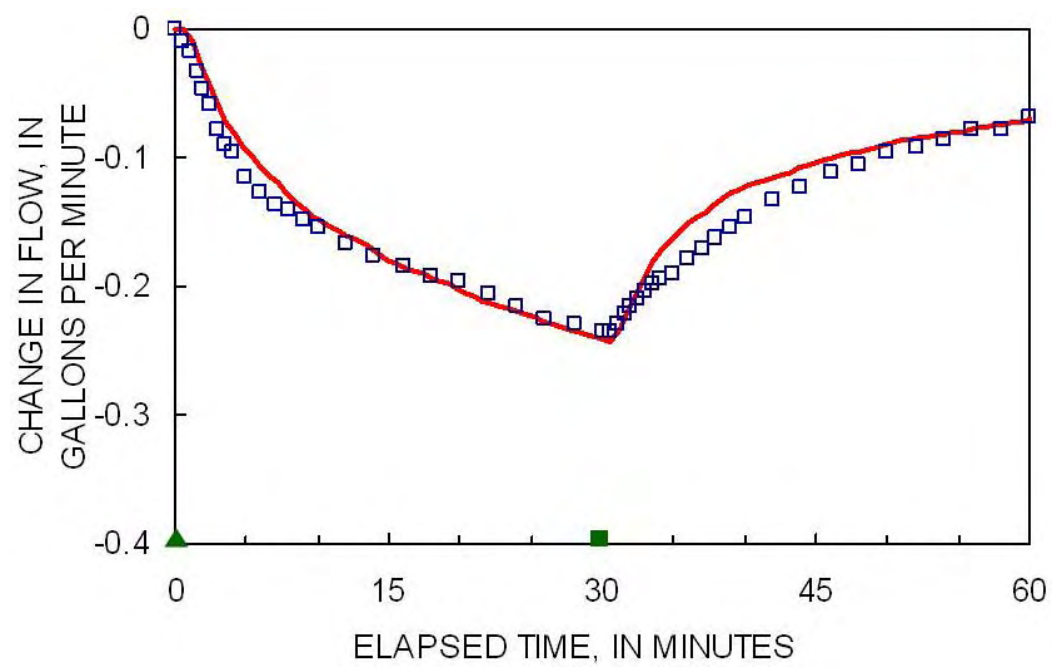

C.

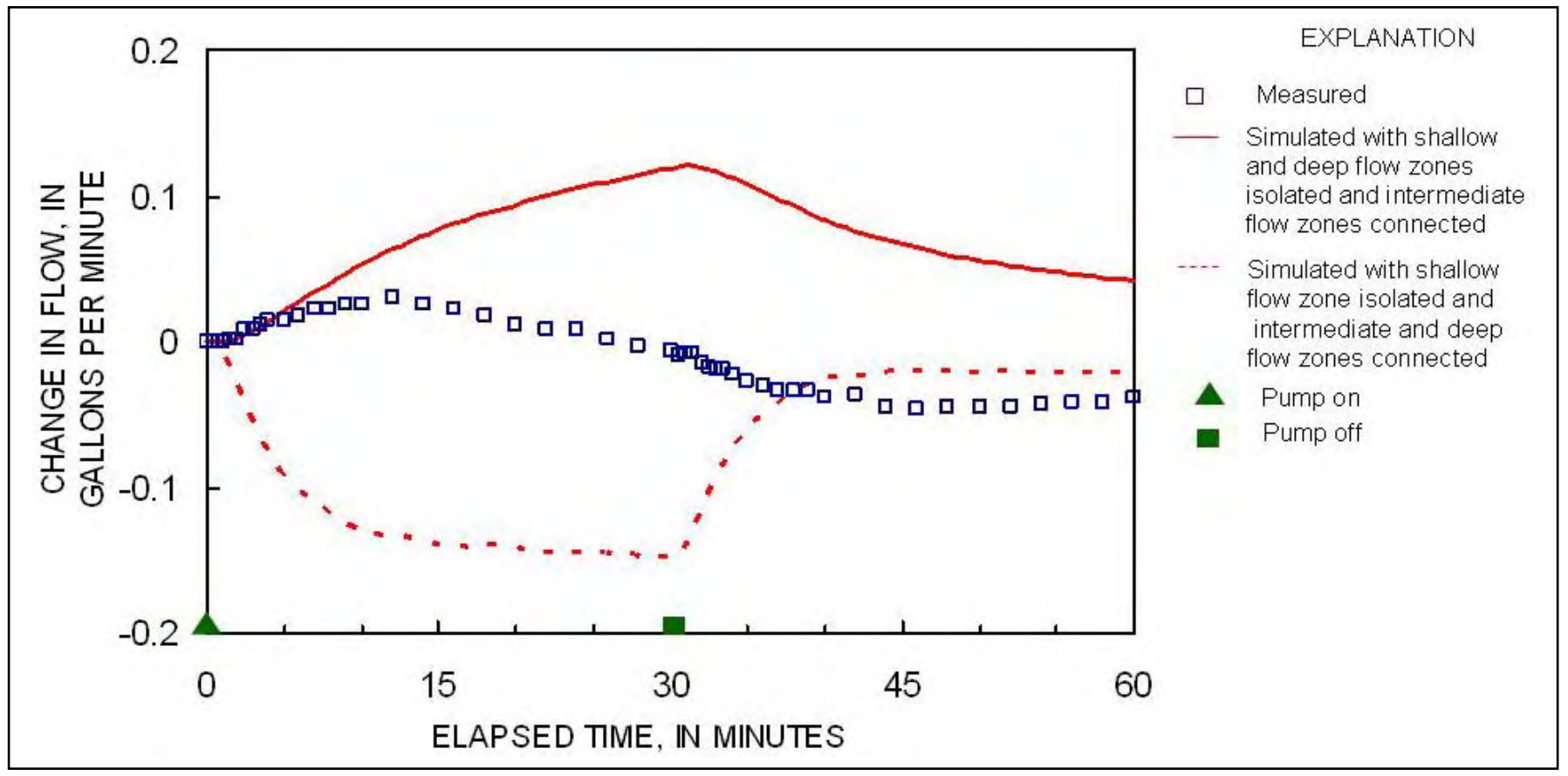

Pumping of well 6BR increased the upward flow during very early time between the deep and intermediate flow zones in corehole 69BR (fig. 10c). During later time, the upward flow gradually decreased, resulting in a lower upflow rate than the ambient rate. Modeling the deep flow zone in corehole 69BR as isolated from the open interval of well 6BR provides simulated flows that reasonably match the measured flows during very early time but at later time depart dramatically as the measured upflow rate peaks and begins to decline as the simulated upflow rate continues to increase. Modeling the deep flow zone in corehole 69BR as connected to the open interval of well 6BR provides simulated flows that are downward, opposite of the measured increase in upward flow during very early time. The departure of the measured flow response from both of the simulated responses suggests the presence of a secondary high-angle connection, which after very early times propagates the drawdown downward across bedding to the deep flow zone from the main connection along bedding. A secondary connection, which cuts across numerous beds and intersects the bedding-dip connection, is consistent with the interpretation from the OTV and ATV logs that the deep flow zone is a high-angle fracture. 


\section{Summary and Conclusions}

The results of the cross-borehole flow tests provided insights into hydraulic connections in the fractured and dipping mudstone and sandstone that are consistent with their lithostratigraphic and structural framework. The cross-borehole flow test in the mudstone identified a hydraulic connection along bedding, which corroborates observations by Lacombe (2000 and 2002) concerning movement of VOCs and propagation of drawdown from extraction-well pumping along and not across bedding units at the site. The cross-borehole flow test revealed a hydraulic connection in the mudstone that was not obvious from the openhole water level response, which was dominated by a shallow zone of high transmissivity that was hydraulically isolated from the pumped interval. In the sandstone, the cross-borehole flow test identified a hydraulic connection along bedding as well as a high-angle connection that cuts across bedding.

Application of cross-borehole flow tests at other contaminated fractured-bedrock sites could provide insights into hydraulic connections useful for the design and implementation of monitoring and remediation programs. Even when more extensive aquifer tests are planned, a series of short-term cross-borehole flow tests can greatly increase the efficiency of the long-term hydraulic tests. Cross-borehole flow tests are compatible with contaminated site work because the tests require boreholes to be open for only a short time, thereby minimizing cross-contamination issues; the necessary hydraulic stress can be provided by short-term pumping or injection from existing single-zone extraction or monitoring wells; and the pumped or injected volumes generated by the tests are minimal.

\section{References}

Lacombe, P.J., 2000, Hydrogeologic framework, water levels, and trichloroethylene contamination, Naval Air Warfare Center, West Trenton, New Jersey, 1993-97: U.S. Geological Survey WaterResources Investigations Report, 98-4167, 139 p.

Lacombe, P.J., 2002, Ground-water levels and potentiometric surfaces, Naval Air Warfare Center, West Trenton, New Jersey, 2000: U.S. Geological Survey Water-Resources Investigations Report 01 4197, $38 \mathrm{p}$.

Paillet, F.L., 1998, Flow modeling and permeability estimation using borehole flow logs in heterogeneous fractured formations: Water Resources Research, v. 34, no. 5, p. 997-1010.

Paillet, F.L., 2000, A field technique for estimating aquifer parameters using flow log data: Ground Water, v. 38, no. 4, p. 510-521.

Shapiro, A. M., 2001, Characterizing ground-water chemistry and hydraulic properties of fractured-rock aquifers using the multifunction Bedrock-Aquifer Transportable Testing Tool (BAT3): U. S. Geological Survey Fact Sheet 075-01, 4 p.

Williams, J.H., and Paillet, F.L., 2002, Using flowmeter pulse tests to define hydraulic connections in the subsurface: a fractured shale example: Journal of Hydrology, v. 265, no. 1-4, p. 100-117. 